\title{
Kohesivitas Suami Istri Dalam Mewujudkan Keharmonisan Rumah Tangga: Studi Kasus Di Gunung Kidulyogyakarta
}

\author{
Suciati \\ Universitas Muhammadiyah Yogyakarta, Jalan Lingkar Barat, Tamantirto, \\ Kasihan, Bantul, Yogyakarta, No Hp: 08156732855 \\ email: suciatiumy@yahoo.co.id,
}

\begin{abstract}
Each couple must have longed for harmony in the household, but it is not a few of those who decideto divorce. The issue is not resolved for the sake ofthe problems cause conflict.This happens when couples are no longer uphold openness and trust. This study raised the marital cohesion in the area of Gunung Kidul Yogyakarta, considering this region occurred in the case of divorce due to lack of harmony in the marital relationship. Data was collected through in-depth interviews with three pairs of husband and wife. The study concluded that the three coupless howed cohesiveness characterized by a relatively high intensity of togetherness, the role of head of the family stay on her husband, satisfaction with the solutions generated and the defense their family name.
\end{abstract}

Keywords: cohesiveness, roles of the family, togetherness intensity, defense good name

\begin{abstract}
Abstrak
Setiap pasangan suami istri pasti mendambakan keharmonisan dalam rumah tangganya, namun tidak sedikit dari mereka yang memutuskan untuk bercerai. Persoalan demi persoalan yang tidak teratasi menimbulkan konflik yang berkepanjangan. Hal ini terjadi ketika pasangan sudah tidak lagi menjunjung tinggi keterbukaan dan kepercayaan. Penelitian ini bertujuan mendeskripsikan kohesivitas suami istri di daerah Gunung Kidul Yogyakarta, mengingat di wilayah ini terjadi kasus perceraian yang tinggi akibat kurang harmonisnya hubungan suami istri. Metode pengumpulan data dilakukan dengan wawancara mendalam dengan tiga pasang suami istri. Hasil penelitian ini menunjukkan adanya kohesivitas yang ditandai dengan intensitas kebersamaan yang relatif tinggi, peran kepala keluarga tetap pada suami, kepuasan terhadap solusi yang dihasilkan serta pembelaan nama baik keluarga.
\end{abstract}

Kata kunci : kohesivitas, peran kepala keluarga, intensitas kebersamaan, pembelaan nama baik

\section{Pendahuluan}

Kehidupan rumah tangga bagaikan sebuah lautan, badai sesekali datang menghampirinya. Banyak orang sepakat bahwa 'badai pasti berlalu', dalam kenyataannya banyak sekali pasangan suami istri yang terpuruk karena badai rumah tangganya tidak kunjung reda. Pada akhirnya tidak sedikit yang memutuskan untuk melakukan "perceraian" sebagai solusi akhir dalam mengatasi badai rumah tangganya.

Banyak ahli filsafat, ilmuwan, sosiologi, psikologi, dan agama menyetujui bahwa problem terbesar dunia adalah problem komunikasi. Problem ini menjelaskan tentang hubungan antar manusia, yang telah memberikan akibat 
yang buruk, hingga adanya pertentangan antar negara, peperangan besar antar suku dan dalam lingkup komunikasi keluarga. Banyak masalah rumah tangga tidak dapat teratasi dengan baik manakala persoalan komunikasi tidak dapat teratasi. Selain komunikasi, tentunya kehidupan beragama juga menjadi pertimbangan sebuah keharmonisan rumah tangga (Stinnet dan DeFrain dalam Dadang Hawari, 1997: 804805).

Kasus perceraian meningkat pesat dari tahun ke tahun. Dengan melihat adanya permasalahan terhadap pernikahan masa kini, ada beberapa pertanyaan yang harus dijawab antara lain; Adakah kemungkinan memperbaiki rumah tangga yang sedang dalam proses kehancuran? Bagaimana Anda dapat membentuk keluarga yang bahagia dan lestari? Di zaman komunikasi global ini, ternyata komunikasi keluarga memegang peranan yang amat penting dan menentukan kebahagiaan rumah tangga. Nancy L. Van Pelt dalam bukunya: Compleat Communication dengan mengutip majalah Redbook, yang telah meneliti sebanyak 730 penyuluh pernikahan, menjelaskan bahwa terdapat sepuluh penyebab utama persoalan rumah tangga (Liwidjaja dan Kuntaraf, 1999:6), (1) Rusaknya komunikasi keluarga; (2) Hilangnya tujuan dan perhatian bersama, (3) Ketidakcocokan dalam seksualitas, (4) Ketidaksetiaan, (5) Hilangnya kegairahan dan kesenangan dalam hubungan suami istri, (6) Keuangan, (7) Pertentangan masalah anak-anak, (8) Penggunaan alkohol, obat bius, dan yang lainnya, (9) Masalah hak-hak wanita, dan (10) Ipar atau mertua.

Pendapat Liwidjaja dan Kuntaraf diperkuat oleh Elizabeth Douvan, yang mengadakan penelitian tentang problema perkawinan di masyarakat Amerika Serikat. Hasil penelitian ini menyatakan bahwa $60 \%$ faktor-faktor yang mempengaruhinyakegagalanperkawinan antara lain (dalam Mar'at, 2005: 245); (1) Pasangan gagal mempertemukan dan menyesuaikan harapan satu dengan yang lain, (2) Salah satu pasangan mengalami kesulitan menerima perbedaan, Masalah keuangan dan anak, (4) Pembagian tugas dan wewenang yang tidak adil, (5) Kegagalan berkomunikasi, (6) Masing-masing pasangan tumbuh dan berkembang ke arah yang berbeda-beda.

Persoalan keluarga tentu juga sangat terkait dengan komitmen masing-masing individu dalam statusnya sebagai suami atau istri. Banyak sekali pertengkaran dalam rumah tangga yang terselesaikan karena munculnya komitmen terhadap keutuhan rumah tangga mereka. Bagi yang tidak memiliki komitmen atau berkomitmen rendah, maka perceraian adalah solusi terakhir dalam penyelesaian permasalahan. Data di Rifka Annisa menyatakan bahwa dari 223 kasus rumah tangga, tak sampai sepuluh persen yang berakhir dengan perceraian selama di dalamnya ada komitmen dan keterbukaan (Republika, 2013).

Fitzpatrick dan kawan-kawan menyatakan bahwa komunikasi keluarga tidaklah bersifat acak (random) tetapi sangat terpola berdasarkan skema-skema tertentu yang menentukan bagaimana anggota keluarga berkomunikasi antara satu dengan lainnya. Skema-skema ini terdiri atas pengetahuan mengenai: seberapa intim suatu keluarga, derajat individualitas dalam keluarga, dan faktor eksternal keluarga (teman, jarak geografis, pekerjaan). Skema tersebut akhirnya melahirkan empat tipe keluarga yaitu; konsensual (sangat melakukan percakapan dan kepatuhan yang tinggi), 
pluralis (sangat sering melakukan percakapan namun tingkat kepatuhan rendah), protektif (jarang melakukan percakapan namun tingkat kepatuhan tinggi) dan laissez-faire (jarang melakukan percakapan dan tingkat kepatuhan rendah). Dalam kenyataan di lapangan keempat tipe ini sering terwujud dalam kombinasi satu dengan lainnya, sehingga terjadi skema keluarga yang bervariasi juga (Morrisan, 2002: 161-162).

Banyak sekali kondisi perkawinan yang mewarnai pada sebuah pasangan. Kondisi ideal bagi setiap pasangan tentu saja sebuah perkawinan yang awet. Kata awet disini bukannya tanpa syarat. Setiap hubungan antar pribadi juga mengandung unsur-unsur konflik, pertentangan pendapat atau perbedaan kepentingan. Johnson dalam bukunya Interpersonal Effectiveness and Self Actualization (Supratiknya, 1995: 9495) menyatakan bahwa sesungguhnya apabila konflik mampu dikelola secara konstruktif, konflik justeru dapat memberikan manfaat yang positif bagi diri sendiri maupun bagi orang lain. Adapun beberapa manfaat positif konflik antara lain: munculnya kesadaran bahwa ada persoalan yang harus dipecahkan, konflik dapat mendorong untuk melakukan perubahan, dapat menjadikan kehidupan lebih menarik, dapat mendorong keputusan yang lebih matang, dapat mempererat dan memperkaya hubungan, sumber hiburan, menyadarkan tentang siapa dan bagaimana diri anggota keluarga serta memecahkan persoalan yang selama ini tidak disadari.

Yogyakartahadirsebagaikotabudaya dan pelajar. Berbagai persoalan termasuk persoalan rumah tangga tidak luput mewarnai kehidupam masyarakatnya. Sebelum tahun 2002, angka perceraian yang tertinggi di DIY terdapat di peng- adilan agama Wonosari, disusul Sleman, Bantul Yogyakarta, dan Wates. Ternyata faktor ekonomi merupakan pemicu pertama untuk perceraian suami istri di wilayah Gunung Kidul. Hampir 70 \%, kasus perceraian muncul karena himpitan ekonomi dan kemiskinan. Adapun faktor pemicu lainnya adalah perselingkuhan yang dilakukan salah satu pasangan (Tribunjogja, 2011).

Suami yang merantau atau bekerja di luar wilayah kabupaten maupun luar negeri sering tidak bertanggung jawab terhadap keluarga. Beberapa kasus perceraian menunjukkan suami banyak yang tidak memberikan kabar kepada istri selama bertahun-tahun. Pada kasus ini istri banyak menjadi korban. Selama ditinggal merantau oleh suaminya, ia juga harus bekerja keras untuk mencukupi kebutuhan ekonomi keluarga. Istri tidak tahan dengan kelakuan suaminya, maka ia mengajukan gugatan cerai terhadap suaminya secara sepihak. Di bawah ini adalah tabel cerai gugat dan cerai talak di kabupaten Gunungkidul pada tahun 2002:

Tabel 1

Data cerai gugat dan cerai talak Kabupaten Gunungkidul tahun 201

\begin{tabular}{|l|l|l|l|}
\hline Bulan & $\begin{array}{l}\text { Cer a i } \\
\text { gugat }\end{array}$ & $\begin{array}{l}\text { Cerai } \\
\text { talak }\end{array}$ & Jumlah \\
\hline Junuari 2011 & 59 & 27 & 86 \\
\hline Februari & 67 & 27 & 94 \\
\hline Maret & 68 & 38 & 106 \\
\hline April & 37 & 39 & 46 \\
\hline Mei & 74 & 29 & 103 \\
\hline Juni & 73 & 25 & 98 \\
\hline Juli & 81 & 36 & 117 \\
\hline Agustus & 83 & 24 & 107 \\
\hline
\end{tabular}

Sumber: (Pengadilan Agama Wonosari, 2012) 
Semua faktor yang terkait dengan hubungan harmonis tersebut akan bermuara kepada kohesivitas suami istri dalam menjaga keutuhan rumah tangganya. Sebuah kohesivitas pada dasarnya terkait dengan sense of belonging masing-masing pihak, baik suami, istri beserta anak-anak mereka. Tanpa kohesivitas maka konflik rumah tangga bahkan perceraian akan menjadi sebuah dampak yang sangat menyedihkan. Korban dampak ini tidak saja pada pasangan yang bersangkutan, tetapi juga pada psikis anak sebagaimana dipaparkan dalam kasus di atas.

Kelangsungan kehidupan kelompok tidak mungkin dapat terbentuk tanpa adanya partisipasi anggotanya. Partisipasi tersebut dapat berupa partisipasi untuk selalu aktif dalam kelompok sampai kepada loyalitas yang tinggi terhadap kehidupan kelompok. Loyalitas tidak mungkin terbentuk tanpa adanya semangat dalam berorganisasi serta hubungan yang akrab dengan anggota lainnya.

Dinamika sebuah kelompok, salah satunya ditentukan oleh kohesi, yang merupakan sebuah kekuatan yang memberikan semangat pada kelompok. Kelompok dengan kohesi yang tinggi akan terlihat adanya rasa ketertarikan diantara anggotanya, menerima tujuan kelompok, serta di antara anggota di dalamnya saling membantu dalam pekerjaan kelompok mereka. Kohesi kelompok semakna dengan solidaritas kelompok. Kohesi atau suatu solidaritas kelompok ditandai dengan kekuatan pertalian yang menghubungkan anggota-anggota kelompok sebagai sebuah kesatuan, adanya rasa memiliki, adanya rasa ketertarikan antar anggota kelompok, serta setiap anggota berusaha untuk mencapai tujuan kelompok
(Vanden Bos, 2006:192).

Kohesif akan memberikan kekuatan yang besar manakala kelompok berada dalam ancaman dari luar kelompok mereka atau dalam suasana kompetisi. Namun demikian kelompok dengan kohesi yang tinggi bukannya tidak bermasalah. Sebuah kohesi dalam kelompok bisa berarti 2 mata pedang, di satu sisi bisa berefek sangat merugikan di sisi lain bisa berarti sangat membantu organisasi (Greenberg dan Baron, 1995: 283-284). Dengan demikian sebuah kohesivitas memiliki sisi positif dan negatif yang akan berpengaruhterhadap kelangsungan keanggotaan dalam sebuah kelompok.

Dalam organisasi manapun kondisi demikian akan muncul apabila kelompok benar-benar memberikan kepuasan terhadap anggotanya untuk tinggal dalam kelompok. Dalam istilah agama disebut sebagai itsar (mendahulukan orang lain ). Dalam militer disebut sebagai esprit des corpses. Dalam kajian psikologi komunikasi hal ini disebut dengan kohesi kelompok, yang meliputi semangat kelompok yang tinggi, hubungan interpersonal yang akrab, kesetiakawanan, dan perasaan in group yang dalam. Dengan demikian maka kohesi kelompok didefinisikan sebagai kekuatan yang mendorong anggota kelompok untuk tetap tinggal dalam kelompok, dan mencegahnya untuk meninggalkan kelompok (Rahmat, 1999: 164).

Sebuah kelompok yang di dalamnya terdiri atas orang-orang yang mempunyai sikap sama akan cenderung lebih kohesif daripada kelompok yang terdiri atas orang-orang yang tidak memiliki sikap yang sama. Kohesi kelompok juga dipengaruhi oleh pertukaran 
komunikasi dalam kelompok. Deutsch, menambahkan bahwa perasaan sesama anggota akan diekspresikan dalam kelompok dalam bentuk sebagai suatu respon yang positif. Adapun efek positip dari sebuah kohesivitas akan terlihat dengan meningkatnya produktivitas melalui meningkatnya motivasi bekerja dalam mencapai tujuan kelompok. Namun demikian dalam kelompok kohesi sangat tidak menoleransi argumentasi atau usulan yang menyimpang dari nilainilai kelompok (Dahnke dan Clatterbuck, 1990: 32-33 ).

Sebuah kohesivitas juga terkait dengan ukuran kelompok dan kepuasan kelompok. Penelitian tentang kohesi dalam kaitannya dengan ukuran kelompok antara lain dikemukakan oleh Seachore pada tahun 1954. Penelitian Seachore dilakukan kepada 228 kelompok kerja suatu pabrik, dengan menghasilkan kesimpulan sebagai berikut: pertama, kelompok yang lebih kecil yang terdiri dari 4-22 orang anggota ternyata rata-rata lebih kohesif daripada kelompok yang lebih besar. Kedua, jangkauan kohesivitas kelompok kecil lebih besar daripada kelompok besar. Penelitian lain dilakukan oleh Mann dan Baumgatel pada tahun 1952 yang menyimpulkan beberapa hal: pertama, adanya indikasi ketidakpuasan disebabkan oleh kohesivitas kelompok yang rendah. Indikasi ini terlihat adanya ketidakhadiran anggota kelompok yang disengaja. Ketidakhadiran tanpa alasan adalah ciri sebuah kohesivitas yang rendah. Semakin tinggi solidaritas semakin rendah ketidakhadiran yang disengaja dari anggota kelompok. Kedua, kepuasan pada kelompok yang lebih besar ditemukan pada kelompokkelompok yang kecil. (Danim, 2004: 289).

David dan Hawari (dalam Rahmat,
1999: 164) mengukur kohesi kelompok dengan tiga hal, yaitu; (1) Ketertarikan anggota secara interpersonal satu dengan lainnya, (2) Ketertarikan anggota pada kegiatan dan fungsi kelompok,(3) Sejauhmana anggota tertarik pada kelompok sebagai alat untuk memuaskan kebutuhan personalnya.

Little John (1999 : 288-289) dalam hipotesis berpikir kelompok lebih menyoroti kepada kekompakan dalam kelompok. Menurutnya kekompakan adalah baik karena dapat membantu dalam sinergi efektif dan meminimalkan energi intrinsik. Ada ciri-ciri negatif dalam kekompakan yang dikemukakan Janis dalam teori ini ; (1) Dalam diskusi kelompok terdapat sedikit alternatif, dan tidak banyak melakukan penelusuran pada teori-teori lain dan kreativitas juga sangat sedikit, (2) Posisi yang didukung oleh banyak anggota tidak pernah dikaji ulang. Dengan kata lain tidak kritis meneliti penyimpangan-penyimpangan dari solusi yang dipilih. (3) Pendapat minoritas dengan cepat diabaikan, (4) Pendapat ahli tidak dicari. Puas dengan dirinya dan mungkin merasa terancam dengan pihak luar, (5) Kekompakan itu sangat selektif dalam mengumpulkan dan memperhatikan informasi yang tersedia. Para anggota cenderung untuk memusatkan hanya pada informasi yang mendukung rencana, (6) Kelompok merasa yakin akan alternatif pilihannya sehingga tidak mempertimbangkan rencana kemungkinan juga tidak meramalkan kemungkinan kegagalan dan tidak mempersiapkan diri untuk gagal.

Menurut Janis, kelompok yang sangat kohesif tergantung pada groupthink. Ada tiga kondisi yang mendorong groupthink (berpikir kelompok), yaitu kohesivitas tinggi dari kelompok pengambil keputusan, karakteristik struktural 
spesifik dari lingkungan dimana kelompok ini bekerja, dan karakteristik internal dan eksternal yang dapat menimbulkan tekanan dari situasi yang ada. Dalam beberapa kelompok kohesi dapat menuntun pada perasaan positip mengenai pengalaman kelompok dengan anggota kelompok yang lain. Kelompok yang sangat kohesif akan sangat antusias mengenai tugas-tugas mereka dan anggotanya merasa dimampukan untuk melaksanakan tugas-tugas tambahan.

Singkatnya, kepuasan yang lebih besar diasosikan dengan meningkatnya kohesivitas. Walaupun terdapat keuntungannya, tetapi kelompok yang kohesif juga dapat menghasilkan hal yang mengganggu groupthink. Janis berpendapat bahwa kelompok dengan kohesif yang tinggi memberi tekanan yang besar pada anggota kelompoknya untuk menaati standart kelompok. Janis meyakini bahwa ketika kelompok mencapai kohesivitas yang tinggi, euphoria ini cenderung mematikan opini dan alternatif yang lain. Anggota kelompok mungkin tidak bersedia untuk mengemukakan keberatan mereka mengenai solusi yang ada. Jadi kohesivitas seringkali menuntun pada ketaatan, dan ketaatan merupakan rute utama menuju groupthink. Kohesivitas secara otomatis menuntun pada groupthink, sebaliknya ketika beraada pada ujung tombak pengambilan keputusan, maka Janis berpendapat bahwa kelompok ini rentan terhadap groupthink (West dan Turner, 2008 : 279-280).

Di sisi lain konsep kohesi kelompok juga dirumuskan oleh Slamet Santosa (1992: 75-78) sebagai berikut, (a) Adanya kesadarankita' diantaraanggotakelomp ok yang lebih kuat, maksudnya adalah bahwa warga lebih sering membicarakan' kita' daripada membicarakan' aku', (b)
Diantara anggota kelompok tampak lebih bersahabat dan setia kawan, (c) Anggota kelompok bersedia membela nama baik kelompok dari serangan/ kritikan dari luar, (d) Anggota kelompok bekerjasama untuk mencapai tujuan bersama yang bertanggung jawab atas maju mundurnya kelompok dan bilamana perlu maka anggota bersedia bekerja keras dan menderita untuk kepentingan kelompok.

Di sisi lain, Scrahter berpendapat bahwa kohesi kelompok dapat terbentuk karena; (a) Adanya persoalan yang sangat penting yang harus dipecahkan bersama, yaitu persoalan yang menyangkut kelompok secara keseluruhan dan tidak mungkin dipecahkan secara perseorangan, (b) Adanya sistem ganjaran dan hukuman (reward dan punishment), (c) Hal ini berarti apabila ada anggota kelompok yang perilakunya sesuai norma kelompok maka ia akan mendapatkan perlakuan yang berbeda dari anggota kelompok lainnya (reward). Apabila ada anggota kelompok yang berperilaku merugikan kelompok secara keseluruhan, maka ia akan mendapatkan tantangan terutama secara psikologis dari anggota kelompok lainnya.

Penyelidikan dari Whyte dan Lippite tentang kelompok-kelompok yang memiliki suasana otokratis, suasana demokratis dan suasana liberal, menyimpulkan bahwa kohesi kelompok akan muncul dalam kelompok yang suasananya demokratis dan tidak pada tipe otokratis dan liberal. Hal ini disebabkan dalam kelompok yang demokratis terdapat rasa solidaritas yang tinggi diantara anggota kelompok.

Roberta A. Baron dan Donn Byrne (2004: 298) mengungkapkan bahwa banyak faktor yang menentukan keter- 
tarikan terhadap orang lain, antara lain kesamaan sikap, keyakinan, nilai, dan minat. Adanya kesamaan dalam keempat hal tersebut, dari satu individu dengan individu lainnya akan menimbulkan ketertarikan, sebab akan meminimalisir konflik yang mungkin muncul karena ketidakcocokan.

Baron dan Byrne (dalam Wirawan, 2009:67-71) mengatakan bahwa daya tarik antar pribadi merupakan penilaian seseorang terhadap sikap orang lain dimana penilaian tersebut dapat diekspresikan melalui suatu dimensi dari strong liking sampai dengan strong disliking. Dengan demikian maka kita menilai orang lain apakah dia cocok menjadi teman kita atau tidak. Adapun ketertarikan ini dipengaruhi oleh tiga hal : faktor internal, eksternal, dan interaksi. Faktor internal meliputi kebutuhan untuk berinteraksi (need for affiliation) dan pengaruh perasaan. Faktor eksternal terdiri atas kedekatan dan daya tarik fisik, sedangkan faktor interaksi terdiri atas dua hal yaitu: persamaanperbedaan (simmilarity- dissimilarity) dan reciprokal liking.

Baron dan Byrne (2004: 5) juga membahas tentang saling ketergantungan dalam sebuah hubungan. Elemen yang umum dari semua hubungan akrab adalah saling ketergantungan (interdependence), yaitu suatu asosiasi interpersonal dimana dua orang secara konsisten mempengaruhi kehidupan satu sama lain, memusatkan pikiran dan emosi mereka terhadap satu sama lain, dan secara teratur terlibat dalam aktivitas bersama sebisa mungkin. Hubungan akrab dengan teman, anggota keluarga dan pasangan hidup meliputi elemen komitmen. Hubungan ini sering disebut sebagai hubungan dengan ikatan berkualitas dengan orang lain.

\section{Hasil Penelitian dan Pembahasan}

Dalam penelitian ini melibatkan tiga pasang informan yang memiliki karakteristik sebagai orang yang bekerja di luar kota dan jarang sekali bertemu dengan keluarganya. Ketiga informan memiliki pekerjaan yang beragam. Informan pertama adalah Sh, seorang wanita yang bekerja di pabrik garmen di Sleman. Informan yang kedua adalah Sa, yaitu seorang sopir truk jurusan Yogyakarta-Surabaya. Adapun informan yang ketiga adalah $\mathrm{Wd}$, seorang pedagang kaki lima yang bekerja di Jakarta.

Temuan penelitian terhadap kohesivitas rumah tangga dari informan Sh, Sa, dan Wd dapat terlihat dalam bagan di bawah ini :

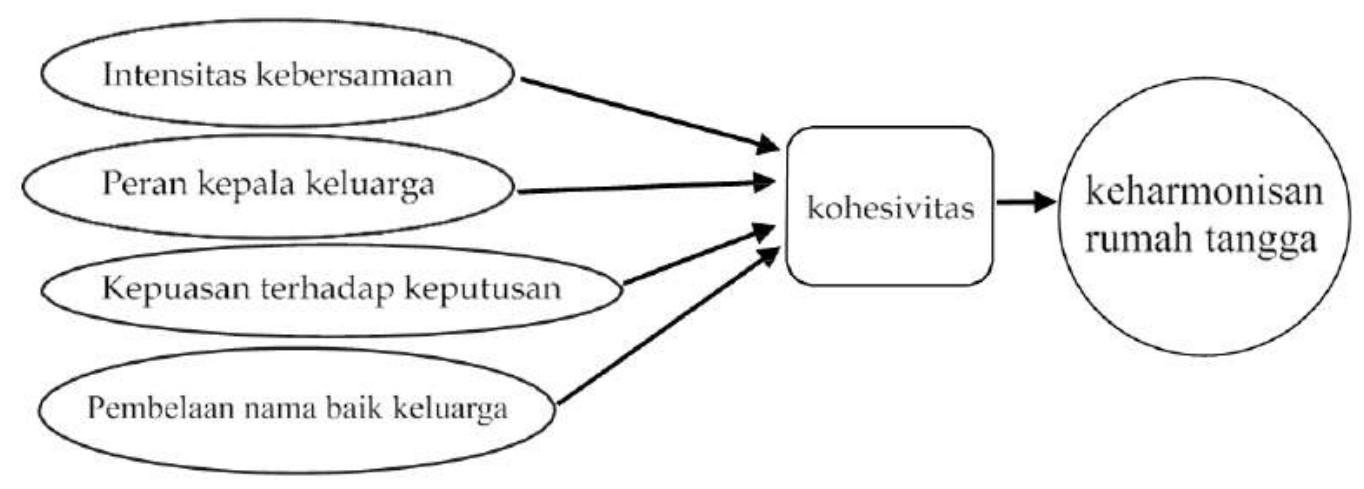

Bagan 1

Faktorfaktor yang mempengaruhi kohesivitas informan 
Berdasarkan bagan 1, dapat dijelaskan lebih rinci pada tabel di bawah ini;

Tabel 2

Keakraban Informan dengan Anggota Keluarga

\begin{tabular}{|l|l|}
\hline Informan & Keakraban \\
\hline Sh & $\begin{array}{l}\text { Selalu berkomunikasi dengan Hp setiap saat, antar jemput oleh suami, jajan } \\
\text { bareng, berkunjung ke rumah keluarga dekat, liburan bersama keluarga }\end{array}$ \\
\hline Sa & $\begin{array}{l}\text { Melakukan telpon dan sms pada saat suami bekerja, melakukan jalan-jalan, } \\
\text { rekreasi bersama anak dan suami ketika berkumpul. }\end{array}$ \\
\hline Wd & $\begin{array}{l}\text { Dua hari sekali telepon, menceritakan tentang apa saja yang dialaminya di } \\
\text { Jakarta, mulai dari penjualan kaos dan tergusur oleh satpol PP, menemani } \\
\text { istri berjualan krupuk di pasar, rekreasi bersama keluarga ketika liburan }\end{array}$ \\
\hline
\end{tabular}

Berdasarkan tabel 2 di atas dapat dijelaskan bahwa ketiga informan cenderung melakukan keakraban demi terciptanya kohesivitas dalam keluarga mereka. Hal yang menarik adalah ketika ketiga informan menggunakan hp sebagai media berkomunikasi setiap waktu. Dengan melihat data tersebut maka keakraban mereka dibentuk oleh beberapa cara yang dapat dilihat pada bagan di bawah ini;

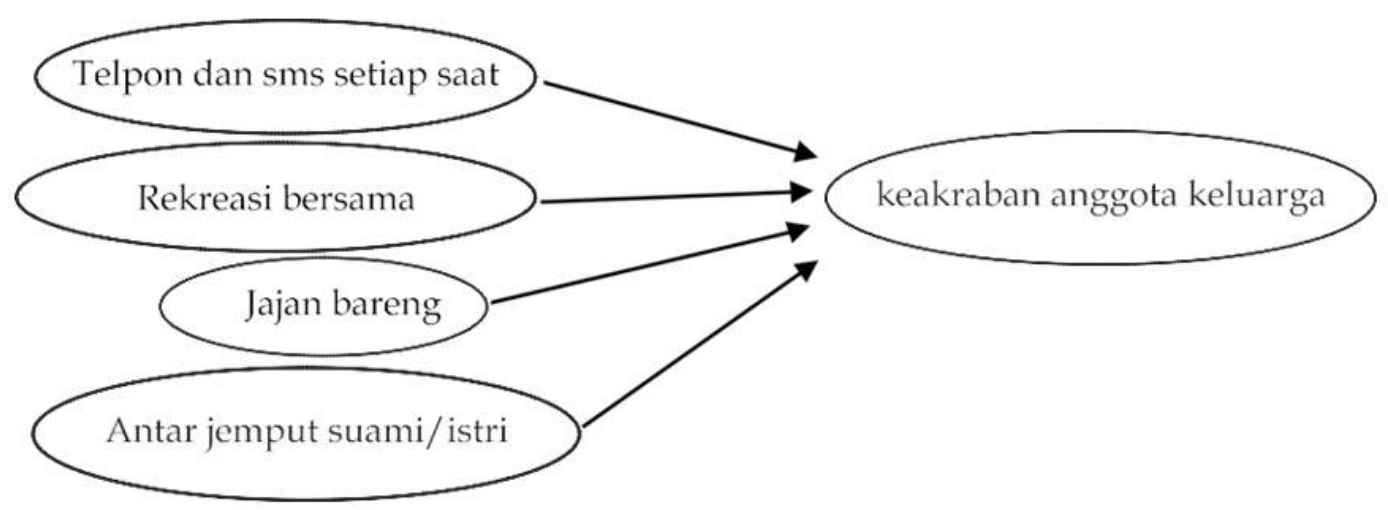

Bagan 2

Caracara informan menciptakan keakraban

Kondisi ini sesuai dengan teori yang dikemukakan Borman (dalam Rahmat, 1999: 164) bahwa dalam kelompok yang kohesif, anggota merasa aman dan terlindungi karenanya komunikasi menjadi lebih bebas, terbuka dan sering.

Suasana umpan balik yang dilakukan Sh dan Sa dengan melakukan komunikasi pada saat pasangan mereka bekerja menujukkan tingkat perhatian yang tinggi. Mereka menyempatkan diri untuk melakukan komunikasi meskipun hanya basa basi, yang hal ini jarang dilakukan. Perbedaan Sh dan Sa adalah jarak waktu menelpon yang telah mereka sepakati. Demikian juga dengan $\mathrm{Wd}$, segala persoalan yang dihadapinya di Jakarta tentang pekerjaannya diungkapkan kepada istrinya, bahkan sampai kepada 
kena gusur oleh Satpol PP.

Sebagaimana yang diungkapkan Borman bahwa suasana bebas, terbuka, dan sering merupakan ciri kelompok dengan kohesivitas tinggi juga dibuktikan oleh informan Sh, Sa, dan Wd. Keterbukaan dalam berkomunikasi juga mereka lakukan pada saat pertemuan tatap muka. Dalam momen tertentu mereka mengungkapkan segala yang dirasakan kepada pasangan dan anak mereka. Mulai dari persoalan dalam rumah tangga, sekolah anak, sampai dengan pekerjaan diungkapkannya dengan jujur. Meski terkadang perlu moment khusus untuk hal-hal yang dirasakan kurang menggembirakan.

Pengontrolan terhadap prestasi anak yang dilakukan oleh informan Sa menunjukkan bahwa ia sangat peduli dan tidak mau keluarganya berbuat kesalahan meski ia tidak menunggui keluarganya setiap saat. Keterbukaan Ga sebagai seorang anak juga menunjukkan adanya kohesivitas yang tinggi meski tidak setiap saat $\mathrm{Ga}$ bertemu dengan bapaknya.

Kekompakan merupakan sebuah kekuatan kelompok baik bersifat positif maupun negatif, yang menyebabkan anggotanya menetap dalam kelompok. Hal ini sangat bergantung kepada tingkat keterikatan individu. Daya tarik antar individu adalah keterikatan dalam arti positip. Para peneliti sering mengukur tingkat kekompakan dengan rasa suka satu dengan lainnya diantara anggota kelompok. Kedua adalah motivasi orang untuk tinggal dalam kelompok. Kita sering berperan dalam kelompok sebagai sarana untuk mencapai tujuan sebagai cara untuk memperoleh pendapatan, untuk melakukan olah raga yang kita sukai atau melakukan pekerjaan lain.
Jadi, ketertarikan terhadap kelompok bergantung kepada kesesuaian antara kebutuhan dan tujuan kita. Ketiga adalah sejauhmana suatu kelompok berinteraksi secara efektif dan selaras.

Adapun hasil penelitian ini juga bisa dikatakan sejalan dengan tesis Wicaksono dan Prabowo (2010: 158) yang menyatakan terdapat faktorfaktor yang menyebabkan munculnya kohesivitas yaitu pengenalan mendalam terhadap orang lain dalam kelompok dan intensitas kebersamaan. Intensitas yang dimaksud di sini bukanlah frekuensi bertemu, namun lebih mengarah kepada kualitas pertemuan. Dengan frekuensi pertemuan yang sangat kecil, ketiga pasang informan mampu membuktikan kohesivitas yang tinggi dalam keluarga mereka. Pertemuan yang jarang kareana terhambat jarak tempat kerja bagi mereka bukanlah halangan untuk menuju keluarga yang harmonis.

Hasil penelitian ini sekaligus menolak teori tentang kedekatan dalam hubungan interpersonal selaras dengan pepatah Jawa "Witing tresno jalaran saka kulino". Dengan kata lain bahwa semakin dekat jarak fisik kita dengan orang lain maka semakin besar kemungkinan bertemu dan akan menghasilkan penilaian positip satu sama lain (more exposure effect) . Bahwasannya kita akan menyukai orang yang wajahnya biasa kita kenali daripada yang tidak kita kenal. Demikian juga dengan daya tarik fisik, maka seseorang cenderung untuk memilih berinteraksi dengan orang yang menarik, karena orang yang menarik biasanya memiliki karakteristik lebih positip. Beberapa penelitian tentang daya tarik fisik menunjukkan bahwa sebagian besar orang percaya bahwa laki-laki atau perempuan yang menarik menampilkan ketenangan, mudah bergaul, mandiri, dominan, gembira, seksi, mudah ber- 
daptasi, sukses, lebih maskulin atau feminin daripada yang tidak menarik. Terbukti bahwa ketiga informan tetap "dekat" meskipun mereka secara fisik berjauhan.

Menurut Nick Stinnet dan John DeFrain, profesor universitas Nebraska
(AS) bahwa pedoman keluarga bahagia bahwa agama dan intensitas komunikasi (Dadang Hawari, 1997: 804-805). Dalam temuan penelitian, terbukti bahwa komunikasi dan kebersamaan dalam tiga pasang informan sudah terbentuk dalam diri setiap informan dan pasangannya.

Tabel 3

Peran Kepala Keluarga Selama Posisi di Perantauan

\begin{tabular}{|l|l|}
\hline informan & Peran kepala keluarga \\
\hline Sh & $\begin{array}{l}\text { Tetap menghormati posisi suami sebagai kepala keluarga, ketika ada masalah } \\
\text { selalu didiskusikan dengan suami }\end{array}$ \\
\hline Sa & $\begin{array}{l}\text { Posisi sebagai kepala keluarga tetap dipegang teguh, permasalahan tentang } \\
\text { keuangan dan anak selalu meminta pertimbangan suami. Memanfaatkan } \\
\text { media telepon dengan sebaik-baiknya. }\end{array}$ \\
\hline Wd & $\begin{array}{l}\text { Selain posisi meminta pendapat tetap dipegang oleh istri, peran mertua di } \\
\text { rumah sangat besar. }\end{array}$ \\
\hline
\end{tabular}

Berdasarkan tabel 3 menunjukkan bahwa ada persamaan dalam menetapkan posisi kepala keluarga ketika mereka tidak berada di tempat tinggal mereka. Permasahannya adalah apakah fungsi mereka sebagai kepala keluarga tetap berjalan dan bagaimana caranya. Ternyata semua informan tetap berprinsip bahwa tidak ada perubahan posisi kepala keluarga termasuk dari sisi fungsinya. Meski berjauhan, masih ada media yang membantu mereka untuk melakukan komunikasi dalam pengambilan keputusan. Anak dan pasangan tetap menghormati bahwa ayahnya adalah kepala keluarga yang berperan dalam pengambilan keputusan keluarga meski jarak mereka jauh. Hubungan pemimpin dan pengikutnya dapat dijelaskan dengan teori leader member exchange ( LMX). Teori LMX melihat hubungan diadic antara atasan dan bawahan yang berada dalam kontinum kualitas tinggi sampai dengan kualitas rendah. LMX tinggi ditandai dengan hubungan antara atasan dan bawahan yang dilandasi rasa saling percaya, rasa hormat, dan tanggung jawab. Sebaliknya kualitas rendah didasarkan pada hubungan kontrak.

Meski dalam kasus Wd, peran mertua juga memegang peranan penting dalam pengambilan keputusan tetapi tetap berada di bawah Wd. Adapun hal yang menarik bahwa ketiga kepala keluarga bukanlah orang yang bertipe otoriter dalam pengambilan keputusan keluarga. Mereka tetap mendiskusikannya dengan pasangannya. Inilah perwujudan dari tipe kepemimpinan LMX, dimana pemimpin mau melakukan sharing dengan anggotanya, sehingga anggota keluarga akan merasa nyaman untuk mengkomunikasikan permasalahan dengan kepala keluarga. Bisa saja, sebagai jalan pintas, pasangan langsung mengambil alih peran kepala keluarga akan tetapi hal ini tidak dilakukannya mengingat kesadaran posisi mereka terkait sebagai 
"kita" bukan "aku."

Posisi "kita" dalam perannya sebagai kepala keluarga masih dihormati sehingga terbentuknya kohesivitas bukan keniscayaan. Hal ini sesuai dengan teori yang diungkapkan oleh Slamet santosa tentang kesadaran "kekitaan" sebagai ciri kelompok yang kohesif. Adanya "kesadaran kita" di antara anggota kelompok yang lebih kuat, maksudnya adalah bahwa warga lebih sering membicarakan' "kita" daripada membicarakan "aku." Di sisi lain anggota kelompok bersedia membela nama baik kelompok dari serangan/ kritikan dari luar dengan rasa "kekitaan" maka mereka akan mempertahankan masing-masing hak dan kewajiban dalam keluarga. Sebagai istri, meskipun bekerja di luar kota, Sh tidak mau melangkahi peran kepala keluarga. Konsep "kita" dalam keluarga tentunya mengakomodasi kepala keluarga, kepala rumah tangga, dan anak. Kekitaan akan membawa rasa kebersamaan dalam keluarga dan menghindarkan dari egoistis yang bermuara pada konflik dan perceraian.

Tabel 4

Bentuk Solusi yang Diajukan dalam Memecahkan Persoalan

\begin{tabular}{|l|l|}
\hline Informan & Solusi yang diberikan kepala keluarga \\
\hline Sh & $\begin{array}{l}\text { Solusi terbaik adalah hasil diskusi berdua, bukan semata-mata kepala keluarga } \\
\text { dominan. Masukan selalu dipertimbangkan oleh pasangan }\end{array}$ \\
\hline Sa & $\begin{array}{l}\text { Masalah dipecahkan bersama. Selalu meminta pertimbangan suami ketika ada } \\
\text { masalah }\end{array}$ \\
\hline Wd & $\begin{array}{l}\text { Ada saling percaya dalam pengambilan keputusan. Peran mertua sangat besar. } \\
\text { Ketika maslah besar maka Wd berusaha untuk pulang menyelesaikannya. }\end{array}$ \\
\hline
\end{tabular}

Tidak heran jika sebuah konflik berasal dari hubungan interpesonal yang kurang baik dari pasangan suami istri. Hubungan suami istri melibatkan pada hubungan interpersonal yang intens. Hubungan interpersonal itu sendiri berlangsung dalam 3 tahapan, yaitu pembentukan hubungan, peneguhan hubungan, dan pemutusan hubungan (Rahmat, 1999: 126-137). Untuk konteks hubungan suami istri tentu hubungan itu sudah tidak pada tataran pembentukan, namun sudah pada peneguhan. Apabila dalam proses peneguhan tersebut terjadi banyak kendala, maka tidak sedikit suami istri yang memutuskan hubungan dengan langkah bercerai.

Hubungan interpersonal tersebut tidaklah statis, namun selalu berubah. Perubahan-perubahan terse- but memerlukan tindakan tertentu dalam rangka menjaga keseimbangan. Ada empat faktor yang amat penting dalam memelihara keseimbangan ini : keakraban, kontrol, respon yang tepat, dan nada emosional yang tepat. Keakraban merupakan sebuah pemenuhan kebutuhan akan kasih sayang. Kesepakatan tentang keakraban yang diperlukan sangat mempengaruhi terpeliharanya hubungan interpersonal ke- dua belah pihak. Faktor kedua terkait dengan siapa mengontrol siapa, dan bilamana. Jika dua orang memiliki pendapat yang berbeda sebelum mengambil kesimpulan, maka siapakah yang 
harus berbicara lebih banyak, siapa yang menentukan, siapa yang dominan. Konflik umumnya terjadi bilamana mereka ingin berkuasa, dan tidak ada pihak yang mau mengalah. Padahal di satu sisi sebuah konflik harus dipahami sebagai sesuatu yang rasional bukan hanya irasional. Konflik akan terjadi ketika satu anggota ingin mendominasi yang lainnya, tanpa kompromi.

Tabel 5

Kepuasan Anggota Keluarga Terhadap Solusi

\begin{tabular}{|l|l|}
\hline \multicolumn{1}{|c|}{ Informan } & \multicolumn{1}{c|}{ Kepuasan terhadap solusi } \\
\hline Sh & Nrima, karena masukan solusi dari suami yang macam-macam \\
\hline Sa & Lebih bersifat ngalah, bersabar, dan mengalah \\
\hline Wd & Ada komunikasi sampai kepada action pada solusi yang disepakati. \\
\hline
\end{tabular}

Kepuasan terhadap solusi yang dipilih oleh pasangan informan pada dasarnya merupakan dampak dari sikap informan yang menghargai posisi kepala keluarga, misalnya nrima, ngalah, sabar, ketika suatu saat solusi kurang menguntungkan satu pihak. Hal ini terkait dengan gaya komunikasi dari suami-istri ketika mendiskusikan permasalahan mereka.

Pengaruh stereotip gender terhadap kohesivitas pernikahan sangat nampak terjadi padangan ketiga pasangan. Istri dalam hal ini menghormati segala keputusan yang sudah dibuat bersama. Hal yang menarik adalah bukan saling membantah dan mendominasi.
Justeru yang terjadi bahwa rasa nrima, mengalah, dan sabar adalah sikap yang dipilihmenghadapikeputusanuntuk solusi yang telah disepakati bersama. Suami merasa bahwa tugasnya tetap harus menjadi kepala rumah tangga yang memutuskan persoalan-persoalan rumah tangga mereka dengan bantuan istri. Sebaliknya istri, meskipun Sh bekerja di luar rumah tetap memposisikan diri bukan pengambil keputusan. Keduanya saling menyadari posisi dalam budaya patrilineal yang masih lekat pada masyarakat Jawa, khususnya Yogyakarta. Selain itu, agama memandang bahwa termasuk perbuatan berdosa jika seorang istri membantah suami.

Tabel 6 Kebanggaan Terhadap Pasangan

\begin{tabular}{|l|l|}
\hline Informan & Kepuasan anggota keluarga terhadap pasangan \\
\hline Sh & Menikmati pekerjaannya meski banyak tetangga yang mempertanyakannya \\
\hline Sa & $\begin{array}{l}\text { Stigma negatif tentang sopir dari masyarakat dibela mati-matian oleh istrinya. } \\
\text { Tetap bersabar menerima anggapan negatif masyarakat. }\end{array}$ \\
\hline $\mathrm{Wd}$ & $\begin{array}{l}\text { Tidak terlalu memikirkan perkataan orang luar yang selalu mempertanyakan } \\
\text { keberadaannya di Jakarta. Wd merasa bangga dengan kemandirian yang } \\
\text { dijalaninya demikian juga istrinya. Termasuk keluarganya juga membantu } \\
\text { dalam menjaga nama baik keluarga. }\end{array}$ \\
\hline
\end{tabular}


Terlihat pada tabel 6 menjelaskan bahwa pada dasarnya ketiga informan menyatakan bangga dengan kondisi suami atau pasangan mereka. Tidak peduli apa jenis pekerjaan yang dilakukannya, namun yang penting mereka bisa hidup mandiri dan halal. Hal ini tercermin dalam perilaku mereka ketika menanggapi pertanyaan atau stigma negatif dari orang luar. Mereka tampak melakukan pembelaan dan yakin bahwa apa yang dilakukan pasangan mereka adalah benar dan tidak melanggar norma dalam masyarakat. Sebagaimana diungkapkan oleh Slamet Santosa di atas bahwa salah satu ciri kelompok yang kohesif adalah kemauan untuk menerima kritikan dari luar. Hal ini ternyata tidak hanya dilakukan oleh pasangan mereka, tetapi perilaku ini juga dilakukan oleh mertua dari $\mathrm{Wd}$ ketika menanggapi pertanyaan tetangga.

Suami isteri harus dilandasi rasa percaya terlebih dahulu terhadap pasangan. Pada prinsipnya ketiga pasangan mempercayai bahwa apa yang dilakukan pasangan di perantauan adalah mencari nafkah untuk keluarga, sehingga anggapan negatif tentang pasangan dapat dibela mati-matian. Rasa percaya itu sendiri adalah syarat mutlak bagi berlangsungnya sebuah hubungan interpersonal yang efektif.

Ada beberapa faktor yang dapat menumbuhkan hubungan interpersonal yang baik : percaya, sikap suportif dan sikap terbuka (Rahmat, 1999: 129-138). Percaya akan menentukan efektivitas komunikasi. Percaya adalah sifat mengandalkan perilaku orang untuk mencapai tujuan yang dikehendaki, yang pencapaiannya tidak pasti dan dalam situasi yang penuh resiko. Untungnya kita percaya kepada orang lain adalah: pertama, percaya meningkatkan komunikasi interpersonal kerena membuka saluran komunikasi, memperjelas pengiriman, memperjelas pengiriman dan penerimaan informasi, serta memperluas peluang komunikan untuk mencapai maksudnya. Kedua, hilangnya kepercayaan pada orang lain akan menghambat perkembangan hubungan interpersonal yang akrab. Bila Anda merasa kawan Anda tidak jujur dan terbuka, maka Anda akan membalasnya seperti itu. Selain itu, bahwa sikap percaya juga dipengaruhi oleh : menerima, empati, dan kejujuran. Rasa percaya informan terhadap pasangannya tidak lepas dari sikap informan yang terbuka. Dengan terbuka maka semua informasi yang masuk tidak akan ditelan mentahmentah oleh informan, meski berita itu berasal dari orang terdekat sekalipun.

Keterbukaan dalam berkomunikasi sering disebut-sebut sebagai syarat pertama langgengnya sebuah perkawinan. Sebuah perkawinan yang awet/langgeng akan menghasilkan kebahagiaan dalam rumah tangga. Namun kebahagiaan rumah tangga bukanlah hal yang diperoleh seketika. Ia harus dikejar, dirawat, ditumbuhkan dan dipertahankan jika pasangan ingin langgeng sampai masa-masa emas. Ada beberapa hal yang perlu diperhatikan dalam upaya ini (Majalah Ummi, 2011: 28); (a) Perbaiki selalu relasi suami istri melalui komunikasi. Tidak boleh merasa gengsi untuk membuka komunikasi terlebih dahulu ketika hubungan mendingin. Relasi pasangan yang baik akan membuat interaksi dengan anak dan lingkungan semakin berkualitas, (b) Memelihara hubungan seks dengan pasangan. Tidak boleh memaknai seks hanya sekedar hubungan badan karena gairah akan menurun seiring dengan bertambahnya usia, (c) Saling memaafkan 
dan membuang rasa dendam dan sakit hati, (d) Selalu memperbaiki hubungan dengan Allah melalui ibadah bersama, (e) Memperbaiki sikap dan perilaku buruk.

Adapun tolok ukur yang dapat dikatakan sebagai komunikasi efektif (Bastaman, 2005:145) antara lain bahwa hal yang dikomunikasikan merupakan sebuah kebenaran, bukan kebohongan. Dengan mengandalkan pada kejujuran pada pasangannya, terbukti ketiga pasangan mampu mempertahankan rumah tangga mereka dari gosip orang-orang disekeliling mereka sehingga membuahkan kepercayaan dan kelanggengan berumah tangga. Bahkan kejujuran ini juga diikuti dengan pembelaan nama baik keluarga.

\section{Simpulan}

Bentuk-bentuk kohesivitas dalam rumah tangga yang dapat dilakukan pasangan suami isteri, antara lain; intensitas kebersamaan, peran keluarga, kepuasan terhadap keputusan yang disepakati, dan pembelaan nama baik keluarga.

Dalam intensitas kebersamaan dilakukan saling bertemu satu dengan yang lain. Sebaiknya melakukan rekreasi bersama atau jajan di luar jika waktunya memungkinkan. Ada pula kegiatan antar jemput pasangannya ketika pulang. Hal yang menarik adalah ketika tidak bias bertemu langsung dapat mengandalkan peran $\mathrm{Hp}$ untuk ber-sms dan telpon dalam berkomunikasi.

Dalam hal peran kepala keluarga, posisi suami sebagai kepala keluarga (di Jawa) tetap dipegangteguh. Permasalahan tentang keuangan dan anak selalu meminta pertimbangan suami. Ketika suami merantau, dapat memanfaatkan media telepon dengan sebaik-baiknya.
Peran mertua dalam pengambilan keputusan juga dilakukan karena tinggal bersama mertuanya. Justeru hal ini sangat membantu dalam pengambilan keputusan rumah tangganya, tanpa harus selalu menggantungkan pada suaminya di perantauan.

Dalam hal kepuasan terhadap solusi, kecenderungan sikap positip yaitu sikap nrima, mengalah, dan bersabar dalam rangka menghormati pasangan sebagai kepala keluarga, secara otomatis Menjadikan mereka terhindar dari konflik.

Adapun pembelaan nama baikkeluarga, pada dasarnya kebanggaan terhadap upaya kepala keluarga dalam mencari nafkah serta kemauan untuk hidup mandiri. Hindari prasangka negatif dari para tetangga terhadap pasangan yang sementara berbeda domisili dalam bekerja. Keluarga besar juga dapat melakukan pembelaan terhadap nama baik keluarga.

\section{Daftar Pustaka}

Baron, Roberta A. dan Byrne, Donn. 2004. Perilaku Organisasi, Ratna Djuwita, Jakarta, Erlangga.

Bastaman, Hanna Djumhana. 2008, Integrasi Psikologi dengan Islam

2005. Menuju Psikologi Islami, Yogyakarta, Pustaka Pelajar.

Dahnke, Gordon L and W Clatterbuck, Glen. 1990. Human Communication: Theory and Research, California, Wadsworth Publishing Company.

Danim, Sudarwan. 2004. Motivasi, Ke pemimpinan, dan Efektivitas Kelompok, Jakarta, Rineka Cipta.

Greenberg, Jerald dan Baron, Robert A. 1995. Behaviour in Organization, Pearson Education Inc, New Jersey.

Hawari, Dadang. 1997. Al Qur'an, Ilmu kedokteran Jiwa dan Kesehatan Jiwa, 
Yogyakarta, Dana Bhakti Prima Yasa.

Little John, Stephen W. 1999.Theories of Human Communication, California, Woodsworth Publishing Company.

Liwidjaja, Kathleen, dan Kuntaraf, Kathleen. 1999. Komunikasi Keluarga, Bandung, Indonesia Publishing House.

Rahmat, Jalaluddin. 1999. Psikologi Komunikasi, Bandung, Remadja Rosdakarya.

Morissan. 2002. Psikologi Komunikasi, Bogor, Ghalia Indonesia.

Mar'at, Samsunuwiyati. 2005. Psikologi Perkembangan, Bandung, Remadja Rosdakarya.

Santosa, Slamet. 1992. Dinamika Kelompok, Jakarta, Bumi Aksara.

Supratiknya. 1995. Tinjauan psikologis Komunikasi Antar Pribadi, Yogyakarta, Kanisius.

Vanden Bos, Gary R. Dictionary of Psychology, Washington DC, American Psicology Association

West, Richard dan Turner, Lynn. 2006. Pengantar Teori Komunikasi: Analisis dan Aplikasi, Jakarta, Salemba.

Humanika.

Wirawan, Sarlito, 2009. Psikologi Sosial, Jakarta, Salemba Humanika.

\section{Internet:}

Republika.co.id. (2013, Desember 10). Suami Istri sering Bertengkar, Haruskah Bercerai. Diakses pada 5 Juni 2014 dari http://www.m. republika.co.id/berita/humaira/ samara/13/12/09/mxjbsu-suamiistri-sering-bertengkar-haruskahbercerai\#

Wicaksono, Bayu dan Prabowo, Hendro. (2010, Juni 2). Kohesivitas Tim Pendukung Sepak Bola Persija. (Tesis, Universitas Gunadarma, 2010). Diakses pada 10 Juni 2014 dari www.ejournal.gunadarma. ac.id/index/php/psiko/article/ download/232/175. h.158

Majalah Ummi. (2011, Juli). Kunci Pasangan Langgeng. h. 28

tribunjogja.com. (2011, Februari 8). Setahun Ada 1.311 Perceraian di Gunung Kidul. Diakses pada 20 September 2011 dari http://jogja. tribunnews.com/2011/02/08/2010perceraian-di-gunungkidul-tercatat1.311-kasus

pa-wonosari.net. (2012, Januari 11). Cerai Gugat. Diakses pada 7 September 2011,http:/ / wonosari.net/index. php?option=com_content\&view $=$ art icle\&id=111\&Itemid $=97$ 